\title{
Türk Dönem Dizilerinde Kullanılan Tarihsel Motiflerin Payitaht “Abdülhamid” Üzerinden
} İncelenmesi $^{1}$

\section{Research of Historical Motifs Used in Turkish Period Series on Payitaht "Abdülhamid"}

\author{
Şina Ceylan Gündüzeri ${ }^{\mathrm{a},}$ Yalçın Lüleci ${ }^{\mathrm{b}}$ \\ ${ }^{a}$ Marmara Üniversitesi, İstanbul Türkiye. \\ sinaceylann@gmail.com \\ ORCID: 0000-0003-4375-6978 \\ ${ }^{\text {b }}$ Dr. Öğr. Üyesi, Marmara Üniversitesi, İstanbul, Türkiye. \\ yalcin.luleci@marmara.edu.tr
}

ORCID: 0000-0002-2957-0352

\begin{tabular}{|c|c|}
\hline \multirow[b]{2}{*}{ MAKALE BİLGİSİ } & ÖZ \\
\hline & \multirow{11}{*}{$\begin{array}{l}\text { Medya, günümüzde bilgiye ulaşmak isteyen bireylerin başvurduğu mecralardan biri haline } \\
\text { gelmiştir. Medya araçları içerisinde olan televizyon, birçok konuda olduğu gibi tarih alanında da } \\
\text { izleyicileri bilgilendirmeye başlamıştır. Televizyon ve sinema gibi görsel işitsel mecralara konu } \\
\text { olan tarih, bu sayede her eve girme firsatı bulmuş ve araştırma yollarına girmeden herkesin tarih } \\
\text { hakkında bilgi sahibi olmasının yolları açılmıştır. Yoruma açı olan tarih, medyanın amacına } \\
\text { hizmet edecek biçimde bir propaganda unsuru haline gelmiş, bu durum kurgusal gerçeklik ile } \\
\text { olgusal gerçekliğin yer değiştirip değiştirmediği sorusunu akıllara getirmiştir. Bu araştırmada, TRT } \\
\text { ekranlarında yayınlanan Payitaht "Abdülhamid" adlı dizideki tarihsel göstergeler, temsil ve } \\
\text { gerçeklik ilişkisi açısından incelenmiştir. Çalışmada, Payitaht "Abdülhamid" dizisindeki } \\
\text { göstergeler Stuart Hall'ın temsil kavramı çerçevesinde ele alınarak yansıtıcı, inşacı ve kasitlı } \\
\text { yaklaşımlar çerçevesinde değerlendirilmiştir. }\end{array}$} \\
\hline & \\
\hline 24.04 .2021 & \\
\hline tarihi: 01.07 .2021 & \\
\hline Kabul tarihi: 02.07 .2021 & \\
\hline Anahtar Kelimeler: & \\
\hline Göstergebilim, & \\
\hline Olgusal Gerçeklik, & \\
\hline Kurgusal Gerçeklik, & \\
\hline & \\
\hline & \\
\hline
\end{tabular}

\section{ARTICLE INFO}

\section{Article history:}

Received: 24.04 .2021

Received in revised form: 01.07.2021

Accepted: 02.07.2021

\section{Keywords:}

Semiotic,

Factual Reality,

Fictional Reality,

Historical Narration,

Art Direction

\begin{abstract}
Media has become one of the channels used by individuals who want to access information today. Television, which is among the media tools, has started to inform the audience in the field of history as well as in many subjects. History, which is the subject of audio-visual media such as television and cinema, has thus found the opportunity to enter every home. In this way, ways have been opened for everyone to have information about history without entering the research routes. History, which is open to interpretation, has become an element of propaganda in a way that serves the purpose of the media, which brings to mind the question of whether fictional reality and factual reality have been replaced. In this research, the historical indicators in the TV series Payitaht "Abdülhamid" broadcasted on TRT screens were analyzed in terms of representation and reality. In the study, the indicators in the series "Payitaht Abdülhamid" were evaluated within the framework of Stuart Hall's concept of reflective, contructor and deliberate approaches.
\end{abstract}

\section{Atıf Bilgisi / Reference Information}

Ceylan Gündüzeri, Ş., Lüleci, Y. (2021). Türk Dönem Dizilerinde Kullanılan Tarihsel Motiflerin Payitaht "Abdülhamid” Üzerinden İncelenmesi. Uluslararası Kültürel ve Sosyal Araştırmalar Dergisi (UKSAD), 7 (1), Yaz, s. 271- 287.

\footnotetext{
${ }^{1} \mathrm{Bu}$ çalışma 2020 yılında yayınlanan "Türk Dönem Dizilerinde Tarihsel Motiflerin Kullanılması Üzerine Bir İnceleme: Payitaht "Abdülhamid" Örneği" isimli tezden üretilmiştir.
}

*DOI: 10.46442 /intjcss.927368

** Sorumlu yazar: Şina Ceylan Gündüzeri, sinaceylann@gmail.com 


\section{Giriş}

Geçmiş çağlardan bu yana insanlar, yaşadıkları devrin önemli olaylarını gelecek nesillere aktarmak istemişlerdir. $\mathrm{Bu}$ amaçla çeşitli yöntemler geliştiren insanlar, tarih öncesi çağlarda duvara çizdikleri resimlerle anlattıkları tarihi, yazının icadından sonra yazılı olarak da aktarmaya başlamışlardır. Geçmişten bugüne kadar yaşanan teknolojik gelişmelerin bir sonucu olarak görsel ve işitsel medya unsurları aracılığıyla aktarılan tarih, bu alanda bilgi edinmek isteyen her bireyin kolaylıkla ulaşabildiği bir alan haline gelmiştir.

Sanayi sonrası toplumlarda insanlar, her şeyi belirlenmiş bir modele göre yapmaktadırlar. İletişim teknolojilerindeki ilerleme sayesinde ise bu modelleme kolaylıkla bireylere aktarilabilmektedir. Kitle iletişim araçları vasıtasıyla aktarılan bu modeller, insanların düşünce ve davranışlarını belirlemektedir. İnsanlar artık gerçeğe bakarak modeli belirlemek yerine, kendilerine sunulan modele bakarak kurgusal gerçekliği belirlemektedirler (Sarı̈ül, 2019, s. 129). Mills'e göre de kitle iletişim araçları bireylere yeni bir kimlik sunmakta ve onlara ne olmaları, nasıl olmaları gerektiğini empoze etmektedir. Ona göre, medya yaşanılan gerçek dünyayı değil, onu okuyan, izleyen ya da dinleyenlere göre oluşturulmuş sahte bir dünyayı yansıtmaktadır. Baudrillard bu durumu medyanın bireylere gerçek dünyayı sunmak yerine gerçeğin teminatıyla doğrulanmış göstergeleri tükettirmesi olarak açıklamaktadır (Sarıgül, 2019, s. 133).

Baudrillard da enformasyon uzamında şeylerin artık bir, iki ya da üç boyutlu değil, bunların arasında bir boyutta yer aldıklarını söyleyerek, gerçek ya da nesnellik kriterlerinin yok olduğunu, bunların yerini gerçeğe benzerliğin aldığını ifade etmektedir (Baudrillard, 2002, s. 169). Ona göre, gerçeklik ile kurmaca arasındaki fark ortadan kalkmıştır. Televizyonda hikâyeleri canlı olarak seyreden izleyiciler, hayatın ve hayatın kopyasının iç içe geçmesine tanık olmaktadır (Baudrillard, 2002, s. 305). İnsanların televizyonda gerçeği değil, onun yeniden üretilmiş halini gördüklerini savunan ve bunu çağımızın en temel hastalığı olarak nitelendiren Baudrillard'a göre, medyanın ortaya attığı bilgi, herhangi bir aksama olmadığı sürece yalanlanmayacak, gerçeğe benzeyecektir. Böylece hep güvenilir kalacaktır ve yalanlandığı takdirde de yanlış olmayacaktır. Çünkü bir şekilde güvenilir hale getirilmiştir. Üstelik sanalda olduğu için de gerçeğin aksine güvenilirliğin sınırları yoktur, kendi kendini çürütmeyecektir (Baudrillard, 2002, s. 170).

Günümüzde en çok rağbet gören iletişim araçlarından biri olan televizyon, gerçekliği yeniden üreterek insanların tarih üzerindeki düşüncelerini şekillendirmektedir. İzleyiciye aktarılmak istenen mesaj, çeşitli görsel unsurlarla verilmektedir. Prodüksiyon aşamasında hazırlanan görsel unsurlar, birçok kişi için bilinmeyeni tasvir ederken, mevcut maddi ve teknik imkânlardan faydalanılarak oluşturulmaktadır. Bu durum, anlatılan olaya karşı yeni düşünme biçimlerinin şekillenmesine, bireylerin hayal dünyasında şahit olamadıkları dönemlere ait unsurların belirlenmesine yol açmaktadır. Mekân, kostüm, döneme özgü dil kullanımı, aksesuar, saç-makyaj ve gelenek, görenek gibi aktarılan döneme ait görsel unsurlar, yukarıda sözü geçen imkânlar çerçevesinde oluşturularak gerçekliği yeniden üretmektedir. Böylece televizyon vermek istediği mesajı ya da ele aldığı dönemle ilgili oluşturmak istediği imajı kolaylıkla bireylere aktarabilmektedir. Böylesi hassas bir noktada ise akıllara, ekrandan sunulan kurgusal gerçekliğin, olgusal gerçeklikle ne ölçüde uyuştuğu sorusu gelmektedir. Bu çalışma, tüm bunlardan yola çıkılarak tarihsel gerçekliklerin televizyona yansıtılırken, temsil yaklaşımları aracılığıyla değişime uğradığı hipotezi üzerine kurulmuştur.

$\mathrm{Bu}$ araştırmada içeriğe etki eden değişiklikler içerisinde yer alan görsel unsurların olgusal gerçeklikle uyuşup uyuşmadığı üzerinde durulmuş, söz konusu değişiklikler temsil yaklaşımları ve göstergebilim bağlamında değerlendirilmiştir. Buradan hareketle araştırma çerçevesinde öncelikle göstergebilim ve temsil yaklaşımları hakkında bilgi verilip sonrasında ise bu bilgiler ışı̆̆ında Payitaht "Abdülhamid" dizisinde, olgusal gerçekliğin kurgusal bir gerçeklik olarak nasıl temsil edildiği üzerinde durulmuştur. 


\section{Tarihin Temsili ve Göstergebilim}

Sinema ve televizyonun günlük hayatta yer edinmesiyle birlikte insan gerçeğin ne olduğunu ararken sıklıkla bu araçlara başvurmaya başlamıştır. Ancak bilgiye erişilebilirlik anlamında kolay olarak görülen bu durum bazı sorunları da beraberinde getirmiştir. Tarihi kendi jargonuna göre aktaran medya, yoruma açık bir alan olan tarihi, amacına uygun bir propaganda unsuru haline getirmiştir. İçeriklerin yapımı aşamasında gerçeklik hakkında farklı görüşlerin oluşmasına sebep olan televizyon, gerçekliği kurgulamak için teknolojik imkânlardan yararlanarak tarihi kendi kuralları çerçevesinde sunmaya çalışmaktadır.

Gerçek dünyanın kitle iletişim araçlarında olduğu gibi yansıtılmamasının en öncelikli sebebi "seçim yapma" zorunluluğudur. Seçme işlemi, ilk olarak iletilmesi gerekenler düzeyinde gerçekleştirilmektedir. Sonrasında ise iletilen olayların öğeleri arasında bir seçim yapılmaktadır. Böylece seyircinin aklındaki görüntüler, gerçek dünyadaki olaylar arasında seçilmiş olanların, seçilmiş yönlendirmeleriyle oluşturulmaktadır (Mutlu, 2008, s. 66).

Televizyon icat edildiği zamandan günümüze kadar bir temsil aracı işlevi görmekte, diğer bir deyişle bir temsil sistemi olarak çalıșmaktadır. Bu durumu daha anlaşılır kılmak ve sağlıklı bir sonuca varmak için öncelikle temsil kavramına değinmemiz gerekmektedir: Stuart Hall temsili, bir şey hakkında anlamlı bir şey söylemek ya da dünyayı anlamlı bir şekilde tasvir etmek için dilin kullanılması olarak tanımlarken, onu aynı zamanda bir kültürün üyeleri arasında anlamın üretildiği ya da değiş tokuş edildiği sürecin bir parçası olarak görmektedir (Hall, 2017, s. 23). Hall, anlam temsilinin nasıl işlediği konusunda üç teori olduğundan bahsetmektedir. Bunlardan birincisi "yansıtıcı yaklaşım”dır. Buna göre anlam, gerçek dünyada yer alan nesnelerde, kişilerde ve fikirlerde yatmaktadır. Dil ise bir ayna işlevi görerek zaten var olan gerçek anlamı yansıtmaktadır. Bunun tam tersini savunan ikinci yaklaşım "kasıtlı yaklaşım"dır ve bilgiyi aktaran kanalın, dünyaya dair kendi öznel yorumunu dil aracılığıyla empoze ettiğini savunmaktadır. Üçüncü yaklaşım olan "inşacı yaklaşım” ise şeylerin kendi başlarına bir anlam içermediğini, bizlerin temsil sistemlerini, kavramları ve anlamları kullanarak onlar için birer anlam inşa ettiğimizi öne sürmektedir (Hall, 2017, s. 34-36). Bu çalışmada, ele alınan Payitaht "Abdülhamid" dizisindeki, göstergebilimsel yöntemle analiz edilen tarihi temsiller, Hall'un bahsettiği temsil yaklaşımları çerçevesinde değerlendirilecektir.

Filmde veya dizide ele alınan tarihsel olayın gerçekliğine dair belgelere sahip olunduğu ve senaryonun buna göre şekillendirildiği durumlar "yansıtıcı yaklaşım" içerisinde değerlendirilmektedir. Ancak, tarihsel olaylar için bazı durumlarda bilgi ve belgelerin tümüne ulaşmak neredeyse imkânsızdır. Ele alınan konu hakkındaki bilginin sadece bir kısmına sahip olunduğunda, eksik kalan kısımlar yönetmen ve teknik ekip tarafından genel kalıplara uygun şekilde tamamlanmaktadır. Bir diğer ifadeyle gerçekliğe belli bir mantık içerisinde eklemeler yapılarak bir kurgu oluşturulmaktadır. Bu durum da "inşacı yaklaşım" içerisinde yer almaktadır. Yapılan eklemelerin gerçeklikten uzaklaşıp, manipülasyon derecesinde varması ise "kasıttlı yaklaşım" olarak değerlendirilmektedir (Lüleci, 2019, s. 190).

İngiliz Kültürel Çalışmaları'na göre medyanın sunduğu içeriklerde sadece iletinin düz anlamı yoktur. Bu mecrada yer alan her metin içerisinde ilk seferde göze çarpmayan gizli anlamlar ve ideolojiler yer almaktadır. Bu bağlamda İngiliz Kültürel Çalışmaları'nın medyada dil, kültür ve ideolojinin incelenmesinde yapısal dilbilim ve göstergebilim teknikleri kullanılmıştır (Yaylagül, 2016, s. 137). Göstergebilim, anlamın nasıl oluşturulduğu ve gerçekliğin göstergeler aracilığıyla nasıl sunulduğu, bir başka ifadeyle nasıl temsil edildiği konusunda çalışmalar yapan bir bilim dalıdır (Yaylagül, 2015, s. 12). Bu sebeple göstergebilim, temsilin nasıl işlediğine dair genel bir model sunmaktadır (Hall, 2017, s. 13). Göstergebilim, metinlerde yer alan göstergelere dayandırılmaktadır. Göstergeler ise gösteren ve gösterilenlerden meydana gelmektedir (Berger, 2018, s.17; Lüleci, 2019, s. 189).

Genellikle kendisi dışındaki bir şeyi temsil etmekte olan ve bu sayede de temsil ettiği şeyin yerine geçebilecek özellikte olan her çeşit nesne, biçim, olgu vb. şeyler gösterge olarak tanımlanmaktadır. Buna 
göre, sözcükler, işaretler ve simgeler bir çeşit gösterge olarak kabul edilmektedirler (Rifat, 2009, s. 11). Gösterilen ise göstergeyi kullanan kişinin ondan anladığı şeydir. Yani gösterilen, göstergenin bağlantısal iki öğesinden biridir. Gösterenin, aracı bir konumda olması onu göstergeden ayıran tek noktasıdır (Barthes, 1979, s. 35). Gösteren ise nitelik bakımından gösterilen ile hemen hemen aynı özellikleri barındırmaktadır. Tamamen bağlantısal bir ögedir ve Barthes'a göre tanım olarak da gösterilenin tanımından ayrılamamaktadır. Göstereni gösterilenden ayıran tek özellik, somut bir karşılık bulmak zorunda olmasidir (Barthes, 1979, s. 40).

Televizyonda göstergebilim bağlamında çözümlenen materyaller "metin” (text) olarak adlandırılmaktadır. Fotoğraflar, reklam afişleri, filmler, duvar resimleri gibi unsurlar da metin (text) kapsamında ele alınmaktadır. Durum komedileri, çizgi filmler, polisiye diziler, soap operalar, reklam filmleri, TV filmleri ve TV dizileri de televizyonun anlatı metinleri arasında yer almaktadır. Göstergebilim de ele aldığı metni biçim ve içerik açısından ayırmakta ve metni oluşturan göstergeler sistemi üzerinde inceleme yapmaktadır. Bu bağlamda, ekranda kısa süreliğine gördüğümüz bir sofrada bulunan patates kızartması, biftek ya da elmalı turta sadece oldukları şey olarak değil, bir sosyal durum, zevk, incelik, milliyet vb. kavramlar olarak anlam bulmaktadır (Parsa, 1999, s. 23).

\section{Dizide Sanat Yönetimi}

Sanat yönetimi genel anlamıyla, tiyatro, sinema ve televizyon gibi mecralardaki sanatsal etkinliklerin planlanmasıdır. Bu alan çerçevesinde, düzenlenecek sahne veya gösteri için bir program hazırlanmakta, mekân, kostüm gibi içeriği destekleyen malzemeler belirlenmektedir (Görsel Sanatlar Platformu , 2008). Tanımdan da anlaşılacağı üzere, bir televizyon dizisinin görsel açıdan gerçeğe ne kadar yaklaşabildiğini analiz etmek için sanat yönetimine ve unsurlarına kısaca bakmak faydalı olacaktır: Filmlerin en önemli özelliklerinden biri gösterdiklerini bir araç haline getirerek göstermediklerini yansıtmaktır. Sinema gösterdikleri açısından çok kesin bir dile sahip olsa bile ima ettikleri açısından oldukça belirsizdir. Bu aşamada da yönetmenin neleri hangi oranda göstereceği ve göstermediklerini nasıl aktarabileceği önem kazanmaktadır (Adanır, 2003, s. 59-60).

Film üretim sürecinin her aşamasında insanlar beraber çalışmakta, bir iş bölümü yaparak kendi uzmanlık alanlarında filmin veya dizinin oluşmasına katkıda bulunmaktadırlar (Kolker, 2009). Bunlar içerisinde yer alan sanat yönetmeni, filme zamansal dokusunu kazandıran ve filmin ortamının şimdiki zamanda ya da geçmişte tanınabilecek setleri, odaları ve dış mekânı detaylı olarak düzenlemektedir. Filmin belli bir tarihsel dönemde geçtiği durumlarda sanat yönetmeninin görevi daha da önem kazanmaktadır (Kolker, 2009, s. 143). Oyuncuların yer alacağı, yönetmen ile görüntü yönetmeninin çekim yapacağı sahneyi hazırlayan sanat yönetmeni, anlatılan hikâyenin dünyasını oluşturmak ve buna dair düşünceleri geliştirmek için grafik sanatçısının, iç mekân tasarımcısının, sanat tarihçisinin ve dekoratörün, tarihçinin, mimarın yeteneklerini bir araya getirmektedir (Kolker, 2009, s. 145).

Sanat yönetmeni, her şeyden önce hikâyeyi en iyi şekilde yansıtacak olan doğal ya da yapay araç ve gereçlerin tümü olarak adlandırılan bezemlerin tasarlanması ve hazırlanmasından sorumludur. Kamera, yönlendirildiği ortamdaki en ufak ayrıntıları bile kaydettiği için, mekân, çevre ve dekor gibi unsurlar son derece titizlik isteyen çalışmalardır. Bu sebeple sanat yönetmeni ve yardımcıları, önce mekân, çevre ve dekorun bir taslağını hazırlamakta, daha sonra ise bunların oluşturulmasına geçmektedirler (Özön, 1985, s. 50). Bu aşamada önemli olan diğer unsurlar ise giysi ve makyajdır. Giysiler için kostüm yaratıcısı devreye girmektedir. Başgiysici olarak da adlandırılan bu görevli hikâyeye uygun giysileri tasarlamaktadır. Bunun yanı sıra kostümü tamamlayacak olan tüm saç ve makyaj işleri ise makyözler ve kuaförler tarafından tasarlanmaktadır (Özön, 1985, s. 51). Dekor, kostüm ve makyaj, dizideki temsillerin niteliğini oluşturmakta önemli bir rol oynamaktadır. 


\section{Payitaht “Abdülhamid”in Görsel Açıdan Değerlendirilmesi}

Bu çalışmada, yapımcılığını ES Film'in, yönetmenliğini Serdar Akar'ın, senaristliğini Uğur Uzunok'un yaptığı ve 24 Şubat 2017 tarihinde TRT 1 kanalında yayınlanmaya başlayıp 4 Haziran 2021 tarihinde ekranlara veda eden Payitaht "Abdülhamid" dizisinin 24 Şubat 2017 ile 23 Haziran 2017 tarihleri arasında yayınlanan ilk sezonundaki tarihsel motifler çeşitli göstergeler yardımıyla incelenecek ve tarihsel gerçeklik ile dizideki temsiller arasındaki ilişki ve farklar ortaya konulmaya çalışılacaktır. Dizi, II. Abdülhamid'in hükümdarlığının son 13 yılını anlatmaktadır. On yedi bölüm süren bu sezonda Sultan Abdülhamid'in padişahlığının 20. yılı olan 1896'dan itibaren döneme damga vuran olaylar konu edilmektedir. Dizinin birinci sezonunda, "Yunan Harbi", 1. Siyonist Kongre, Filistin toprakları meselesi ve Hicaz Demiryolu projesi gibi olaylar ele alınmaktadır.

Payitaht "Abdülhamid'in ilk sezonunda II. Abdülhamid rolünü oyuncu Bülent İnal canlandırmaktadır. Bülent İnal'a, Theodor Herzl rolüyle Saygın Soysal, Tahsin Paşa karakteriyle Bahadır Yenişehirlioğlu, Mahmud Paşa canlandırmasıyla Hakan Boyav ve Bidar Kadın rolüyle Özlem Conker eşlik etmektedir. Bu isimlerin yanı sıra Şehzade Abdülkadir'i Can Sipahi, II. Abdülhamid'in kız kardeşi Seniha Sultan'ı Selen Öztürk, V. Murat'1n kızlarından Hatice Sultan'1 Gözde Kaya ve Fehime Sultan'1 ise Elif Özkul canlandırmaktadır. Dizinin çekimleri, İzmit'te bulunan Seka Film Platosu'nda yapılmaktadır. Yıldız Sarayı'nın belirli mekânlarının inşa edildiği plato dışında İstanbul'da Yıldız, Dolmabahçe ve Eyüp bölgeleri ile Yalova ve İzmit'te de dış çekimler yapılmaktadır.

\subsection{Mekân Unsurlarının Analizi}

Payitaht "Abdülhamid" dizisinde en fazla kullanılan mekan, II. Abdülhamid'in saltanatı süresince en fazla kullandığı saray olan Yıldız Sarayı'dır. Sultan II. Abdülhamid, Dolmabahçe Sarayı'nda amcası Sultan Abdülaziz'e düzenlenen darbeye şahit olmuştur. Şehzadelik döneminde yaşadığı bu olay, Dolmabahçe Sarayı'nın güvenliğinden şüphe duymasına sebep olmuş; bu nedenle de padişah olduktan sonra Yıldız Sarayı'na yerleşmiştir (Engin, 2018, s. 75). O dönemde çok büyük olmayan saray arazisi sadece Büyük Mabeyn Dairesi, Şale, Malta, Çit ve Çadır Köşklerini içermekteydi. II. Abdülhamid, arazinin sınırlarını genişleterek, içerisine çeşitli binalar yaptırmıştır. Şehir içerisinde yeni bir şehir haline gelen saray içerisinde sultanlar ve şehzadeler tarafindan konut olarak kullanılan ve resmi görevlilere tahsis edilen köşklerin yanı sıra tiyatro, müze, kitaplık, eczane, hayvanat bahçesi, mescit, hamam, tamirhane, bıçkıhane, ayar ve çini atölyeleri, demirhane ve kilithane gibi çeşitli binalar bulunmaktaydı (Sevgin, 1966, s. 40). Yani, Yıldız Sarayı, kısa sürede inşa edilip padişahın hemen taşındığı bir saray değildir, inşası ve padişahın kullanımına açılması aşama aşama olmuştur.

II. Abdülhamid önceki padişahlar tarafından av sahası ve hususi bir mesire alanı olarak kullanılan Yıldız Sarayı'nın (Engin, 2018, s. 74) bulunduğu bölge ilk olarak II. Abdülhamid dönenimde sürekli bir ikametgâh olarak kullanılmaya başlanmıştır. Yıldız'a ilk geldiğinde Hünkâr Kasrı'nda ikamet eden Sultan Abdülhamid, kendi dairesini yaptırmadan önce bir bahçe inşa ettirmiştir. Selamlık Bahçesi denilen bu bahçe aynı zamanda "Has Bahçe" ya da "İç Bahçe" olarak da bilinmektedir (Dağgülü, 1993, s. 1). Abdülhamid tahta çıkmadan önce mesire alanı olan bu bahçe, sarayın Yıldız'a taşınmasıyla birlikte 1876 ve 1909 yılları arasındaki dönemde padişaha ait özel bir bahçe statüsüne gelmiş, sınırları genişleyen bu bahçede çeşit çeşit bitki ve çiçek yetiştirilmiştir (Dağgülü, 1993, s. 2). Saray böylece sadece devlet işlerinin görüldüğü resmi bir bina olmanın ötesine geçip haneden üyeleri için çok fonksiyonlu olan bir yaşam alanına dönüşmüştür.

Dizi içerisinde Yıldız Sarayı'nın meşhur bahçesinin bahsi sıklıkla geçmektedir. Görsel açıdan ise söylemlerdeki kadar sıklıkla vurgulanmasa da izleyicinin bu konu hakkında fikir sahibi olabilmesi için çeşitli detaylara yer verilmiştir. Dizide büyük bir bahçe yerine boğaza bakan küçük bir bahçe ve seyir terası minvalinde bir kamelya kullanılmaktadır. Oldukça küçük olan bu bölüm kocaman bir bahçeden ziyade bir köşkün arka bahçesi havası taşımaktadır. Bunun yanı sıra seyirci, çok nadir de olsa Şehzade 
Abdülkadir'in bahçe gezintilerinde bu mekânı görmektedir. Gezintilerden birinde Şehzade, saray bahçesinin büyüklüğünden ve çeşitliliğinden bahsetmektedir. Öte yandan farklı mekân çekimlerinden Yıldız Sarayı mekân çekimlerine gelindiği zaman kullanılan sahne geçişlerinde sarayın kuşbaşı görüntüsü verilmektedir. Söz konusu bu görüntülerde sarayın ne kadar büyük bir alana yayıldığı ve yeşillikler içerisinde olduğu izleyiciye sunulmaktadır.

Yıldız Sarayı'nın bahçesinde yer alan bitkilerin çeşitliliği ise dizideki olaylara konu edilmiştir. Dizinin sekizinci bölümünde Sara Hedeya'nın saraya geri dönmesini sağlamak amacıyla kullanılan zehrin bu bahçede yetişen bir bitkiden elde edildiği vurgulanmaktadır. Burada izleyiciye Kuzey Afrika'ya bir ilim heyeti gönderildiği ve bu heyetin Yıldız Sarayı'nın bitki familyasına oradan getirdikleri bitkileri de eklediği bilgisi verilmektedir. Bu şekilde saray bahçesinde yetişen bir bitki, bir olayın kilit unsuru halini getirilmiş; böylece seyircinin saray bahçesinin zenginliği konusunda da fikir sahibi olması sağlanmıştır. Görsellikten çok bu tarz sözlü içeriklerle vurgulanan saray bahçesinin kurgusal gerçekliği olgusal gerçeklikle uyum sağlamaktadır ve yansıtıcı temsil yaklaşımına bir örnek olarak karşımıza çıkmaktadır.

Sarayın dizide de kullanılan bir diğer bölümü Küçük Mabeyn ise 1900 yılında Sultan II. Abdülhamid'in emriyle yapılmıştır. Küçük Mabeyn, II. Abdülhamid tarafından oturma ve çalışma dairesi olarak kullanılmış olup yemek, istirahat, kabul ve yatak odaları bulunan bir ev olarak inşa edilmiştir (Sevgin, 1966, s. 44). Küçük Mabeyn'in mekân olarak kullanıldığı dizinin birinci bölümünde tarihin 1896 olduğu vurgulanmaktadır. Ancak) Küçük Mabeyn yukarıda da ifade edildiği gibi 1900 yılında inşa edilmiştir. Yani bahsedilen yıllarda henüz böyle bir bina yoktur. Tarihsel açısından değerlendirildiğinde Küçük Mabeyn'in temsilinde inşacı bir temsil söz konusudur. Ancak, binanın dış temsili gerçeklik açısından herhangi bir sıkıntı içermemekte ve bina orijinal haliyle uyumlu şekilde temsil edilmektedir. Bunun yanı sıra dizi içerisinde de bina gerçek inşa amacına uygun kullanılmaktadır: II. Abdülhamid'e ait bir çalışma odası içermekte ve çeşitli siyasi mevzular burada konuşulmaktadır. Yani Küçük Mabeyn görsel açıdan değerlendirildiğinde yansıtıcı temsil yaklaşımı bağlamında değerlendirilebiliriz.

Dizide Yıldız Sarayı'nın bir diğer mekânı olan Şale Köşkü de sıklıkla izleyicinin karşısına çıkmaktadır. Şale Köşkü, farklı dönemlerde tamamlanmış olan birbirine bitişik üç binadan oluşmaktadır. İlki 1880, ikincisi 1889 yılında tamamlanan binalardan üçüncüsü olan Merasim Köşkü, II. Abdülhamid zamanında Almanya İmparatoru'nun İstanbul'u ikinci ziyareti münasebetiyle 1898 yılında inşa ettirilmiştir (İrez, 1988, s. 28). Ahşap ve kâgir karışımı bir bina olan Şale Köşkü bir restorasyon çalışmasından geçirilmiş ve ahşap olan bölümleri beyaza boyanmıştır (Arıburun, 2012, s. 99). Dizide canlandırılan Şale Köşkü' nün II. Abdülhamid dönemindeki görüntüsünden ziyade restorasyon yapılmış yeni görüntüsüne benzediği gözlemlenmektedir. Bu durumda tarihi gerçekliği yansıtmak adına dijital ortamda benzeri oluşturulan Şale Köşkü, anlatılan dönem görüntüsünden çok bir restorasyon çalışmasından geçtiği anlaşılan günümüzdeki beyaz ahşaplı görüntüsüyle temsil edilmektedir. Binanın dış kısımlarına yönelik dizide kullanılan diğer detaylar da yine günümüzdeki renklere uygun şekilde yapılmıştır. Yalnızca giriş kısmındaki peyzaj düzenlemesinde çeşitli farklılıklar görülmektedir. Asıl halinde giriş kısmında yalnızca çimler ve birkaç ağaç bulunurken, dizi için tasarlanan halinde giriş bölümünün etrafi yeşil yapraklarla kapatılmış, bitkilerden bir çit oluşturulmuştur.

Şehsuvaroğlu, Şale Köşkü’nün II. Abdülhamid döneminde en gösterişli günlerini yaşadığını söyleyerek dönemin önemli siyasi kişiliklerinin burada konuk edildiğini belirtmektedir. Şehsuvaroğlu, bu davetlerin verildiği Şale Köşkü’ndeki Merasim Salonu'nun geceleri tavana asılı olan üç adet berrak avize ve yine aynı berraklıkta karşılıklı olarak yerleştirilmiş ayaklı ve çok kollu şamdanlar tarafından aydınlatıldığı bilgisini vermektedir. Bunun yanı sıra dekorasyonla ilgili ayrıntıları da veren Şehsuvaroğlu, salonun zemininde özel olarak tasarlanmış, üzerinde renkli çiçek desenlerinin bulunduğu, göbekli ve bordürlü tek parçadan oluşan büyük bir Hereke halısının olduğunu söylemektedir. Bu bilgilere göre salonun ortasında avizelerin altına denk gelecek şekilde üzeri mermerden yapılmış ve kıymetli vazolarla süslenmiş masalar yer almaktaydı. Bu eşyaların yanı sıra duvar kenarlarındaki sehpalı vazolar, şömineler ve üzerindeki 
kıymetli küçük eşyalar ile duvarlardaki aynalar salonun aksesuarlarını oluşturmaktaydı. Büyük salonun kuzey ve doğu cephelerine açılan yirmi üç penceresinde de nal biçiminde altın yaldızlı kornişlere takılı olan Hereke kumaşından yapılmış perdeler ve kenarlarında aynı kumaştan yapılma sandalyeler bulunmaktayd1. Salonun koridora ve yandaki odalara açılan beş adet kapısı ise tavandakilerle uyum halinde olan altın yaldızlı çiçeklerle süslenmişti (Şehsuvaroğlu, 2011, s. 139).

Dizide Merasim Salonu, Büyük Mabeyn binasının bir bölümü şeklinde gösterilmektedir. Ayrıca Şale Köşkü görüntüsünün ardından Bidar Kadın'ın odası olarak kullanıldığı söylenen bir salon gösterilmekte ve Bidar Kadın ile Şehzade Abdülkadir arasında bu salonda geçen bir diyaloğa yer verilmektedir. Bu durum Şale Köşkü'nün içerisinde hareme ayrılmış bir bölüm olduğu izlenimi uyandırmaktadır. Ancak Şale Köşkü’nde bir harem bölümü bulunduğuna dair herhangi bir tarihsel veri bulunmamaktadır. Bunun yanı sıra Şale Köşkü'nün devlet işlerine ayrıldığına dair herhangi bir detaya da yer verilmemiştir. Devlet meseleleri ya da siyasete dair olan sahneler ya Büyük Mabeyn ya da Küçük Mabeyn binalarında veya sarayın genel görünümünün ardından verilmektedir.

19. yüzyıl, Osmanlı mimarisinde Batı'nın etkisinin görülmeye başladığı bir dönem olarak karşımıza çıkmaktadır. Saray mimarisinde başlayan bu eğilim zaman içerisinde kendini mobilya ve dekorasyon alanlarında da göstermiştir. Ancak bu yönelime rağmen dönemin saraylarının bazı bölümlerinde Türk gelenekleri de terk edilmemiştir (İrez, 1988, s. 33). Yıldız Sarayı'nın mobilyaları incelendiğinde, Şale Köşkü’nde yer alan mobilyaların Rokoko ve Gotik tarzda olduğu görülmektedir (İrez, 1988, s. 67). Yani Batılı tarz burada da kendini gösterme imkanı bulmuştur.

Sarayda kullanılan bütün mobilyaların tarzları ve renklerini öğrenmek gibi bir imkanımızın olmaması nedeniyle, çalışmamızı ancak hakkında bilgi toplayabildiğimiz detaylar üzerinden sürdürmeyi zorunlu kılmaktadır. Bu konuda ayrıntılı bilgi edinilen yerlerden biri II. Abdülhamid'in yatak odasıdır. Elde edilen verilere göre bu oda, Rokoko tarzıyla döşenmiş olup, renk olarak uçuk pembe ve mavi tonları kullanılmıştır (İrez, 1988, s. 67). II. Abdülhamid'in çalışma odasında ise uçuk pembe, altın sarısı ve beyaz gibi tonlar kullanılmıştır. Şale Köşkü'nde bulunan ve günümüzde Sedefli Salon olarak bilinen yemek salonunun sedefli kapıları da Çırağan Sarayı'ndan getirtilmiştir. Bu salonda yer alan mobilyalar da altın yaldızlarla süslenmiş ahşaptan yapılmıştır. Zemindeyse krem rengi kullanılarak üzeri gece mavisi çiçek desenleri bulunan bir kumaşla kaplanmıştır (İrez, 1988, s. 72).

Dizide tasarlanan mekânlardaki mobilyalara bakıldığında modern çizgilerin var olduğu; ancak dönemin hâkim stillerinden Rokoko üslubunun ağırlıkta kullanıldığı görülmektedir. Öte yandan Türk kültürünü yansıtan unsurlar da eksik edilmemiş, dönemi yansıtan aksesuarlar ve sedir gibi yine Türklerin kullandığı mobilya stilleri çeşitli mekânlarda kullanılmıştır. Dizi içerisindeki kullanılan salonların dekor açısından olgusal gerçeklikten uzaklaşıldığı gözlemlenmektedir. Dizi içerisinde Bidar Kadın'ın odası olarak Şale Köşkü'nde yer aldığı söylenen salon da bunlardan bir tanesidir. Bu salonun, dekor açısından dönemin şartlarıyla uygunluk içerisinde olduğu görülmekte, ancak harem dairesinin bulunduğu binanın temsil yeri eldeki verilerle uyuşmamaktadır. Dizide kullanılan diğer mekânlara bakıldığında ise mobilya tarzı dışında renk ve yerleşim açısından elde edilen bilgilerle bir uyum görülmemektedir. Bu durum sarayın her odasına dair bilginin mevcut olmamasından ileri gelmektedir. Yönetmen birçok mekân için eldeki sınırlı veriden faydalanmış, ancak çoğunlukla verilerden elde ettiği parçaları birleştirmiş, eksik kalan kısımları kendi inisiyatifi doğrultusunda tamamlamıştır. Bu açıdan bakıldığında Şale Köşkü'nün temsili de inşacı temsil yaklaşımına uygun olarak şekillendirilmiştir.

Dizide temsili oluşturulan bir başka bina ise Büyük Mabeyn'dir. Büyük Mabeyn, Yıldız Sarayı'nı çevreleyen duvarların dışında inşa edilmiştir. Binanın iç tasarımı altınla bezenmiş kapılardan, duvarlardan ve tavandan oluşmaktadır. Büyük bir çini soba ve kristal avizeler de mekânın iç tasarımını meydana getiren diğer unsurlardır. II. Abdülhamid, asıl saray bölümünde yer alan bu binaya 1877 yılında yerleşmiştir ve alt kattaki salon ile onu takip eden üst kattaki salonu resmi odası olarak kullanmıştır (Sevgin, 1966, s. 44). Büyük Mabeyn'in bilgisayar üzerinden oluşturulmuş dış temsiline bakıldığında 
birkaç ufak peyzaj düzenlemesi dışında kurgusal gerçekliğin olgusal gerçekliğe yaklaştı̆̆1 gözlemlenmiştir.

Dizide bölüm içerisinde mekânların birbirinden ayrıştırılması için iç sahnelerden önce binaların dışarıdan görüntüsü verilmekte ve hangi bina olduğu ekranın sol alt kısmında yazılarak seyirciye bilgi verilmektedir. Söz gelimi eğer sahne Büyük Mabeyn içerisinde yer alan bir mekânda ise izleyiciye önce Büyük Mabeyn'in dış temsili gösterilmekte sonrasında ise iç mekânda geçen sahne izlettirilmektedir. Dizide Büyük Mabeyn olarak bilgisi verilen bir sahnenin ardından II. Abdülhamid'in devletin çeşitli kademelerinde görevli paşalarla yaptığı bir toplantı görülmektedir. Bu toplantının yapıldığı oda, Sultan'ın farklı törenler düzenlediği, resmi toplantılar yaptığı bir oda olarak dizi süresince sık sık karşımıza çıkmaktadır. Dizideki temsilden yola çıkılarak Büyük Mabeyn'in resmi devlet işlerinde kullanıldığ 1 sonucuna varılmaktadır. Bu durum ise daha önce belirtilen II. Abdülhamid'in burada resmi odalarının bulunduğu bilgisiyle uyum göstermektedir. Ancak kullanılan salon, daha önce de belirtilen Şale Köşkü'nün Merasim Salonu'dur. Salonun temsiline bakıldığında olgusal gerçekliği ile uyumlu olduğu gözlemlenmiştir. Ancak, salon dekor olarak günümüzdeki haliyle uyum halinde temsil edilmiş olsa dahi içinde bulunduğu bina Büyük Mabeyn değil, Şale Köşkü’dür. Olgusal gerçekliğin yansıtıldı̆̆ı dekor konusunda yansıtıcı temsil yaklaşımı görülürken, Merasim Salonu'nun Büyük Mabeyn içerisinde gösterilmesi de inşacı temsil yaklaşımının bir örneği olarak karşımıza çıkmaktadır.

Tüm bunların yanı sıra dekor açısından tüm mekânlarda kullanılan ortak unsurlar incelendiğinde dizi süresince hemen her odada kullanılan avizeler dikkat çekmektedir. Dönemin şartlarına bakıldığı zaman da avize kullanımının lüks yaşamda yer edindiğine ancak elektrik ile aydınlatılamadığı bilgisine ulaşılmıştır. II. Abdülhamid'in Yıldız Sarayı'na yerleşmesiyle birlikte ilk elektrik tesisatı 1898 yılında Yıldız, Şale Köşkü'ne döşenmiştir. Ancak II. Abdülhamid'in yangın tehlikelerine karşı beslediği endişe nedeniyle kullanılamamıştır. II. Abdülhamid, İstanbul'daki yapıların çoğunluğunun ahşap olması ve ufak bir kıvılcımla ciddi sonuçlar doğurabilecek yangınların ortaya çıkabileceği endişeyle, genel elektrik kullanımına izin vermemiştir (Karahüseyin, 2009, s. 30). Bu şartlar altında saraylarda görülen ş1k avizeler, havagazı ve mumlu aydınlatmaya uygun şekilde tasarlanmıştır (Karahüseyin, 2009, s. 32). Aydınlatma araçları içerisinde dizide farklı mekânlarda sık sık görülen ve göze çarpan ilk araç ise yukarıda değindiğimiz sebeplerden ötürü şamdanlardır. Özellikle kırmızı rengin yoğun olduğu kristal şamdan sıklıkla arka planlarda yer almaktadır.

Dizinin çeşitli sahnelerinde olaylar sarayın koridorlarında geçmektedir. II. Abdülhamid'in Aile Albümü ismiyle yayınlanan ve sarayın çeşitli bölümlerinin fotoğraflarının yer aldığı kitapta Şale Köşkü içerisinde yer alan bir koridor görülmektedir (Yılmaz, 2009, s.52). Bu koridorda, karşılıklı olarak dizilmiş gösterişli, şık vazolar ve şamdanlar bulunmaktadır. Dizi içerisinde gösterilen koridorlarda vazolar, orijinaldeki gibi sıklıkla yer almamakta, gerçek görüntünün aksine daha sade ve gösterişsiz bir dekor görülmektedir.

Dizi içerisinde dikkat çeken bir başka dekor unsuru ise Arapça tablolardır. Üzerlerinde dini ibarelerinin yer aldığı tablolar özellikle Sultan II. Abdülhamid'in marangozhanesinde göze çarpmaktadır. Sultan'a ait bir mekân olarak temsil edilen bu alanda hat sanatıyla yazılmış dini içerikli yazılardan oluşan tabloların yerleştirilmesi Sultan'ın muhafazakâr bir kişilik olarak temsil edildiğini göstermektedir. Bu tarz dini göstergeler, Sultan'ın sıklıkla dini ifadeler kullanmasıyla söylem olarak da desteklenmektedir. Bu çerçeveden bakıldığında II. Abdülhamid yönetiminin muhafazakâr ve dini hassasiyetleri gözeten bir temsili söz konusudur. Durumun olgusal gerçekliği incelendiğinde de Sultan II. Abdülhamid'in dini itikada sahip bir Müslüman olduğu ve ibadetlerini aksatmadığı şeklinde bilgilere de ulaşılmaktadır (Osmanoğlu, 2008, s. 24).

\subsection{Kullanılan Kostümlerin İncelenmesi}

Televizyon içeriklerinde kullanılan kostümler izleyicilere bilgi veren sanat yönetimi unsurları içerisinde yer almaktadır. Özellikle tarih dizilerinde önemli bir yere sahip olan kostümler, anlatılan dönemin 
zihinlerde daha net canlanmasını sağlamaktadır. Böylece izleyiciler dönemin kültürü hakkında da fikir sahibi olabilmektedirler. Bu sebepledir ki tarih dizilerinde tercih edilen kostümler ve bunların senaryonun geçtiği tarihsel dönemle uyumu son derece önem taşımaktadır. Üstünde durduğumuz nedenlerden ötürü Payitaht "Abdülhamid” te kullanılan kostümler de araştırma kapsamında incelenmiştir. Konunun daha anlaşılır bir şekilde aktarılması için erkek ve kadın kostümleri sırasıyla incelenmiş, ardından dizideki temsilleri değerlendirilmiştir.

Osmanlı'da Batı'nın etkisinin yaygınlaşması giysi modası üzerinde etkili olmuş ve erkek giyimi geleneksel dönemdeki tarzdan ayrılmaya başlamıştır. Tanzimat Dönemi ile birlikte başlayan giyimde yenileşme hareketleri redingotun alaturkası olarak isimlendirilen alaturka setrenin giyilmesiyle yaygınlaşmıştır. Bu dönemlerde ayakkabı için ise çekme potin ya da arkası sustalı galoş kunduralar tercih edilmiştir. Ayrıca rugan ve glas iskarpin, yandan düğmeli bağlı potinler, lastikli çekme potinler, burunları bazen sipsivri, bazen düz kesik şekilde olan ayakkabılar da modaya uygun bir şekilde kullanılmıştır (Özer, 2014, s. 135). Redingot diz kapağının altına kadar uzayan, geniş etekli ve arka kısmı yırtmaçlı alafranga bir cekettir. Bu yıllarda yakası kolalı Frenk gömleği, boyun bağı, yelek ve redingot ile aynı kumaştan yapılan pantolonlar erkek giyiminin modasını oluşturmuştur. Redingotlar siyah dışında gri renkte de yapılır; ancak bu renk aşırı alafranga zenginler tarafından özel hayatlarının gerektirdiği durumlarda kullanılmıştır (Koçu, 1969, s. 197).

II. Abdülhamid zamanında yaygınlaşan redingotlar, tek başına giyilemediğinden ve abdest alma konusunda zorluklara sebebiyet verdiğinden bunu giyenler "beynamaz" olarak adlandırılmış ve bunların yerini de istanbulinler almıştır. İstanbul terzileri tarafından tasarlanan, diz kapağına kadar uzanan, beli dar, eteği ve omuzları geniş bir giysi olan İstanbulin, göğüs kısmının kapalı ve dar olması sayesinde gömleksiz ve kravatsız giyilebilmekteydi (Özer, 2014, s. 376). Yaşlı devlet erkânının çoğu ve yüksek memurlar, sarayda ve resmikabullerde redingot yerine kolalı gömlek ve kravata gerek kalmayan önü tamamen kapalı olan İstanbulin giymiştir (Koca, 2009, s. 73). Ancak bazı kaynaklarda İstanbulin kullanımının II. Abdülhamid devrinde yerini tamamen redingota terk ettiği de söylenmektedir (Koçu, 1969, s. 134).

Dizide paşa rolünü canlandıran oyuncular üzerinde istanbulin tanımlamalarına uyan kostümler görülmektedir. Genellikle bu kostüm içerisinde görülen paşaların üzerindeki ceketler ile redingotlar arasında sadece ceketlerin kesimi konusunda bir farklılık gözlemlenmektedir. Etek kısmı geniş olan istanbulinlerin aksine dizide dar kesim ceketler tercih edilmiştir. Bu durum redingot üzerine giyilen ceketler ile istanbulinler arasındaki farkı neredeyse ortadan kaldırmıştır. Böylece paşaların giyim tarzının genel giyim modasından ayrılmasının dizi içerisinde de gözetilmiş olduğu görülmektedir. Bu noktada yansıtıcı bir bakış açısından söz etmek mümkünken, kıyafetlerin kesimleri açısından oluşan farklılıklara bakıldığında inşacı bir yaklaşımın olduğu da gözlemlenmektedir.

$\mathrm{Bu}$ dönemde üst tabakadan kişilerin giydiği redingot ve istanbulin gibi şık kıyafetlerin aksine esnaf daha sade giysiler tercih etmiştir. Yeni moda ceketler yerine tercih edilen mintanın etekleri kalçaları örtecek uzunlukta olup, önü entari gibi yarım yırtmaçlıdır. İç gömleğin üzerine giyilen mintan, uzun kollu ve düz yakalıdır. Esnaf takımının giymeye devam ettiği bir diğer giysi çeşidi ise poturdur. Potur, bacağa denk gelen kısımları dar olan bir şalvardır. Ön tarafı pantolon önü gibi olmasına rağmen pantolondan ayıran en büyük özelliği diz kapaklarına kadar pantolon bacağı kesimi gibi indikten sonra geri kalan kısımların baldırlara sımsıkı yapışmasıdır (Koçu, 1969, s. 194). Yine aynı dönemde bele kuşak bağlama modasının da devam ettiği görülmektedir. Dış kuşaklar, şalvar, çakşır, potur ve mintan üzerine sarılarak kullanılmıştır (Koçu, 1969, s. 161).

Diziye bakıldığında esnaf giyimi konusundaki bu ayrımın gözetildiği gözlemlenmektedir. Saray halkı ve diplomatlardan sonra esnaf kostümlerine bakıldığında aradaki bu fark izleyiciye yansıtılmıştır. Ancak İstanbul delikanlılarının yukarıda anlatılan tarzda giyindiği bilgisine rağmen dizide Ömer karakterini canlandıran Akın Akınözü’nün kostümlerinde yünlü boğazlı bir kazak tercih edildiği görülmektedir. 
Oysa, dönemin modasına bakıldığında ise böyle bir tarzın olduğu konusunda herhangi bir veri elde edilememektedir. Bu noktada inşacı bir temsilin söz konusu olduğu görülmektedir.

Giysi alanında yaşanan reformlar, kıyafetlerin tamamlayıcı olan aksesuar kullanımında da kendini göstermiştir. Osmanlı'da boyunbağı da denilen kravat kullanımı Avrupai setre ve pantolon giyilmesiyle birlikte görülmüştür. 1860 ve 1865 yılları arasında halk arasında da yaygınlaşan kravat, özellikle gençler arasında hem şıklık hem de alafrangalık göstergesi olarak kullanılmıştır (Koçu, 1969, s. 43). Bu dönemde klasik boyunbağının yanı sıra plastron adı verilen büyük boyunbağları da kullanılmıştır. Plastronlar geniş bir boyunbağıdır ve bol bir düğümle bağlanılarak takılmıştır. Düğümün geniş olması sebebiyle dışarıda kalan uçları gömleğin önüne yayılır ve ön kısmı tamamen kapatılırdı. Dügüumün ortasına ise bir inci veya pırlanta taşıyan bir iğne takılırdı. Çoğunlukla Avrupai hayatı benimseyen kibar tabaka tarafından tercih edilen plastronlar aydınlar, edipler ve diplomatlar tarafından da kullanılmaktaydı (Koçu, 1969, s. 45).

Dizide alafranga giyim tarzının en bariz temsilleri Mahmut Paşa karakterini canlandıran Hakan Boyav'ın kostümlerinde gözlemlenmektedir. Mahmud Paşa, Batı hayranıdır ve Osmanlı'nın İngiliz sömürgesi altına girmesi gerektiğini savunmaktadır. Alafranga hayat tarzını benimsemiş olan Mahmud Paşa karakteri için redingot tercih edilmiştir. Mahmud Paşa kostümü için kravat yerine sıklıkla plastron boyunbağı kullanılmıştır. Avrupai hayat tarzını tercih eden kişiler tarafından kullanılan plastron, dizideki kostüm içerisinde bu durumun bir göstergesi olarak izleyiciye sunulmaktadır. Bu tercihler, karakterin Batı hayranı olduğunun bir göstergesi olup, olgusal gerçeklik ile uyum göstermektedir.

Dizi içerisinde plastron kullanımına bir diğer örnek ise Şehzade Abdülkadir karakterini canlandıran Can Sipahi'nin kostümleridir. Şehzade Abdülkadir de Batı yaşantısından övgülerle bahsetmekte ve Osmanlı'nın geri kalmasından şikâyet etmektedir. Bu açıdan bakıldığında Sipahi'nin kostümleri içerisindeki plastron tıpkı Mahmud Paşa gibi Şehzade Abdülkadir'in de düşüncelerinin bir göstergesi olarak karşımıza çıkmaktadır. Ancak Şehzade'nin redingotlarında bordo renk kullanılmıştır. Bu dönemde redingotlarda siyah dişında gri rengin kullanıldığı; fakat onun da çok tercih edilmediğine daha önce değinmiştik. Bu durumda kostüm renkleri konusunda inisiyatif kullanıldı̆̆ı ve dönem içerisinde kullanılmayan renklere dizide yer verildiği gözlemlenmekte, inşacı temsil yaklaşımı bağlamında değerlendirilmektedir.

19. yüzyılın sonlarına gelindiğinde İstanbul kadınlarının hak arama mücadelelerini dışavurum biçimlerinden biri de kılık kıyafet alanında Batı'ya benzeme istekleri olmuştur. Kadın modasının değişimini tetikleyen ve yeni bir moda anlayışının yaygınlaşmasına sebep olan bu durum, başta saraya mensup kadınlar arasında görülmüş ve sonrasında ise alt kesimlere doğru yaygınlık göstermiştir. Bu dönem incelendiğinde kadınların ev içerisinde giysilerini süslemek amacıyla çeşitli aksesuarlardan eskiye nazaran daha sık ve gösterişli bir şekilde yararlandığı görülmektedir. Yine bu dönemde Avrupa ile ilişkilerin artması giyim kuşama etki etmiş ve kadın giysilerinde oyalar, danteller, yaldızlı geniş parlak harçlar kullanılmaya başlanmıştır. Sonrasında ise pile, korsaj ve yaka gibi ayrıntılarla daha köklü değişimler görülmeye başlanmıştır. Bilhassa saray ve çevresinde yaşayan kadınlar değişen yaşam tarzından etkilenmiş ve yüzyılın son çeyreğinde tamamen Batılı özellikler taşıyan giysileri ya doğrudan Paris'ten ya da buradan gelen moda dergilerinden gördükleri modelleri terzilerinden 1smarlamaya başlamışlardır (Özer, 2014, s. 337). Sınırlı bir çevrede de olsa Osmanlı kadını bu konudaki gelişmelere yabancı kalmamıştır.

Bir çeşit geçiş dönemi yaşayan Osmanlı kadın giyim modası geleneksel olan ferace ve yaşmak alışkanlığını korurken, yeni beğenilerden de geri kalmamıştır. Bu dönemin kadınları uzun yakalı, bol ve rengârenk feracelerinin üzerine yüzlerini kapatmak için kullandıkları yaşmaklar iyice incelmiş, üzerlerine çeşitli oyalar eklenerek süslenmiştir. Ellerine ise genellikle giysileriyle takım oluşturacak küçük şemsiyeler almışlardır (Özer, 2014, s. 341). Bu dönemde yüzyıllar boyunca önü açık entari altına şalvar olarak giyilen ve "üçetek entari" olarak adlandırılan geleneksel giysiler yerini önü kapalı, şalvarsız, tek parçadan oluşan ve balenlerle vücuda oturtulan giysilere bırakmıştır. "Teketek" denilen bu elbiselerin 
önlerinde gögüs altlarına kadar bir açıklık bulunmaktadır (Görünür, 2010, s. 49-51). Yine aynı dönemde bu elbiselerin yanı sıra etek ve bluzdan oluşan önü kapalı yırtmaçsız entariler de kullanılmaya başlanmıştır (Görünür, 2010, s. 52). Yani giyim seçenekleri çeşitlenmiştir.

Bu yıllarda kadınlar elbiselerini tamamlamak amacıyla zenginliklerine göre mücevher de kullanmışlardır (Apak, 1997, s. 127). Baş süslemelerine de ayrı bir önem veren kadınlar, saçlarına ince örükler yaparak incili kurdelelerle bağlamışlardır. Baş yapılarına göre küçük veya büyük olarak yapılan hotozları da saçların üzerine oturtarak kullanmışlardır. Önü yüksek, arkası açık olan hotozların etrafı da tıpkı mücevherlerde olduğu gibi zenginlik derecesine göre çiçekler, değerli taşlar ve pırlantalı iğnelerle süslenmiştir. Yarım taç şeklinde süsler ve tüyler de takılan hotozlar, sırma ipekli başörtüsüyle beraber kullanılmıştır. Hane dışında ise evdeki tarzdan farklı olarak vücudu topuklara kadar kapatan ve vücut hatlarını gizleyen uzun kollu feraceler tercih edilmiş, baş ve yüz kısımları ise yaşmak ile örtülmüştür (Apak, 1997, s. 128). Böylece ev içindeki ve kamusal alandaki giyim bu şekilde farklılaşmıştır.

Osmanlı İmparatorluğu'nda padişahın ve sarayda yaşayan kişilerin kıyafetleri ve bunların kumaşları halkın giyiminden farklılık göstermekteydi (Apak, 1997, s. 18). Osmanlı'da saraya getirilen Türk, Gürcü ve Çerkez kızları içerisinde padişahın nikahına aldığı kişi olan başkadın efendi, samur kürk giyerek şahsına ait bir dairede yaşardı. Kadın efendiler, omuz, sırt ve yakaları kürklü, tabanı sevai kumaştan yapılan bir elbise giyerlerdi. Bu kadınların elbiselerinin bir kısmına da "tepe-başı" denilmekteydi. Tepebaşı, üzeri sırma işlemeli ağır kumaşlardan dikilmekteydi. Kumaş için ise altın sırma işlemeli sevai kumaş tercih edilmiş, bunun yanı sıra "simsiye" adlı kumaşlar da kullanılmıştır. Kadın efendilerin kullandıkları hotozlar da güzel renklerden, tepesi sipsivri, değerli taşlar ve çiçeklerden yapılmıştır. Tepesine tüylerin de yerleştirildiği hotozların bir kısmında da tepelik bulunmaktaydı. Uzun saçlarını topuz yaparak başlıklarının üst kısmına dolayan kadın efendiler boyunlarına değerli gerdanlık takarken, kulaklarına ise yine değerli taşlardan yapılmış olan küpeler takmaktaydılar (Apak, 1997, s. 61).

Payitaht "Abdülhamid” dizisinde dönemin başkadın efendisi Bidar Kadın'ı canlandıran Özlem Conker için dizinin geçtiği yıllarda yayılmaya başlayan ve "teketek" ya da "biretek" olarak adlandırılan elbiselerden oluşan kostümler seçilmiştir. İlk bölümlerde tarz olarak Osmanlı’yı çok fazla yansıtmayan elbiselerin yanı sıra zaman zaman Osmanlı motifleri kullanılan elbiseler de gösterilmiştir. Öte yandan dönemin gereklerine uygun olarak harem dışında başı ve yüzü kapatan kostümler de tercih edilirken, herhangi bir hotoz kullanımı görülmemektedir. Ancak dönemin kadınlarının zenginliklerine göre taktıkları takılar ve süslerin gereği olarak hem başörtü kısmında değerli taşlar hem de gerdanlık, küpe vs. gibi mücevherler sıklıkla görülmektedir.

Hotozlarda tüy kullanımı detayı dizide padişahın kız kardeşi Seniha Sultan'ı canlandıran Selen Öztürk’ün kostümlerinde sıklıkla gözlemlenmektedir. Ancak bu tüy bir hotoz üzerine değil, arkadan sarkıtılan ince bir başörtüyle birlikte saçlara takılmış olarak görülmektedir. II. Abdülhamid'in kızı Ayşe Osmanoğlu hatıratında, Seniha Sultan'ın çok iyi kumaşlardan alafranga tarzda elbiseler giydiğini ve eteğini arkaya bıraktığını söylemektedir. Osmanoğlu, Sultan'ın saçlarının erkek gibi kesik olduğunu ve hiç uzatmadığını da belirtmektedir (Osmanoğlu, 2008, s.49). Diziye kostüm açısından bakıldığında, anlatılanlarla bir uygunluk görülse de saç konusunda aynı uyum gözlemlenememektedir. İzleyici Selen Öztürk'ü Seniha Sultan karakterinde uzun saçlarıyla seyretmektedir. Hatta bazı sahnelerde uzun ve dümdüz saçlarıyla da seyircinin karşısına çıkmaktadır.

Saray cariyeleri sultanlardan daha farklı bir giyim tarzına sahipti. Acemi, cariye, şağird, usta ve gedikli olarak beş sınıfa ayrılan cariyelerden gedikli cariyeler, kırmızı renkli kaftan, uzun elbise, şalvar ve yemeni giymekteydiler. Bel kısmı için kuşak veya mücevher işlemeli kemerler kullanan bu cariyeler, kışın kolları ve omuzları kürklü kaftanlar kullanmışlardır. "Üçetek entari” olarak adlandırılan giysiler bu dönemde cariyeler tarafından kullanılmaya devam ederken halk tarafından da tercih edilmekteydi. Belden aşağısı iki parçaya ayrılarak önü açılan ve bu bölümü de şalvarla tamamlanan bu giysilerin üç parçadan oluşması cariyelerin hizmet ederken rahat ve hızlı hareket etmesini sağlamaktaydı. Kaftanların içine 
giyilen bol dökümlü, bluz havasındaki göyneklerin yaka ve kol uçları volanlar, firfırlar vb. şeylerle süslenmekteydi (Apak, 1997, s. 129). Yani, saray mensuplarının da konumlarına ve yaptıkları işlere göre şekillenen bir giyim tarzı vardı.

Saray hayatına dair hatıralarını yazan II. Abdülhamid'in bir diğer kızı Şadiye Osmanoğlu ise, saraya getirilen kızların yerlere kadar uzanan kuyruklu, belleri büzmeli etekler giydiklerini söylemektedir. Osmanoğlu, eteklerin kuyruk kısmının, belleri büzen yandan sıkıștırılarak yukarı toplandığını aktarmaktadır. Şadiye Osmanoğlu'nun saray giyimine dair aktardı̆̆ 1 bir diğer detay ise saraya geldiklerinde isimleri değiştirilen bu kızlara verilen yeni isimlerin küçük bir karta takıldığı ve türbanların üzerine iğnelendiğidir (Osmanoğlu Ş. , 2012, s. 35).

Dizide saray cariyelerinin ortama göre farklı kostümlerle temsil edildiği görülmektedir. Dizinin geçtiği yıllarda üçetek kültürünü devam ettiren cariyeler dizi içerisine teketek modasına uygun kostümler içerisinde temsil edilmektedir. Cariyelerin harem dışındaki alanlarda başörtü ve yaşmak kullanımı ise dönemin modasına ve giyim kültürüne uygunluk göstermektedir. Ancak başörtü kısımlarında herhangi bir isim detayı bulunmamaktadır. Dizi içerisinde etek bluz kombinleri de yer almaktadır. Kadın karakterler üzerinde bu kombini kullanan karakterlerin aynı eteğin farklı tonlarını giydiği görülmektedir. Üst parça ise kimi zaman bir gömlek kimi zaman ise dantel ya da firfırlarla süslenmiş bluzlarla kombinlenmiștir. Söz konusu yıllarda ortaya çıkmaya başlayan etek-bluz modasını temsil için kullanılan bu kostüm, daha çok modern bir görüntü vermekte ve 19. yüzyıl sonlarına ait olan gerçeklerinden kumaş, görüntü ve kesim gibi açılardan farklılık göstermektedir (Görünür, 2010, s. 52).

\subsection{Abdülhamid'in Görsel Temsili}

Sultan II. Abdülhamid'in iktidar yıllarını konu alan Payitaht “Abdülhamid”de elbette ki padişahın da nasıl temsil edildiği önem taşımaktadır. Söylemleriyle II. Abdülhamid hakkında bir izlenim oluşturan dizide, görsel araçların kullanımı da söylemleri desteklemesi ve en az söylemler kadar fikir oluşturması açısından oldukça önem taşımaktadır. II. Abdülhamid hakkında detaylı bilgiler, kızı Ayşe Osmanoğlu'nun Babam Sultan Abdülhamid ve Başkâtibi Tahsin Paşa'nın Yıldız Hatıraları isimli hatıratlarında yer almaktadır. Dış görünümü hakkında bilgi veren Osmanoğlu, II. Abdülhamid'in orta boylu, saçı ve sakalı kumral biri olduğunu söylemektedir. Padişah'ın saçlarının tepeden dökülmüş; ancak yanlardan gür olduğunu anlatan Osmanoğlu, gözlerinin de yeşil ve mavi arasında bir ela olduğunu aktarmaktadır. Osmanoğlu, Sultan'ın kaşlarının da çok kalın olmayıp, burnunun yüksek, Osmanlı hanedanına mahsus bir tipte olduğunu, saçlarının tepeden dökülmüş, sesinin ise kalın ve gür olduğunu belirtmektedir (Osmanoğlu, 2008, s.11).

Ayşe Osmanoğlu II. Abdülhamid'in giyim tarzı konusunda da çeşitli bilgiler vermiştir. Buna göre, Sultan II. Abdülhamid, sade giyinen ve abartıdan hoşlanmayan biridir. Resmi günlerde tabii olarak üniforma giyen Padişah, haremde koyu gri tonlarında elbiseler giymiş ve aynı renkte pantolonlar kullanmıştır. Elçileri ve paşaları kabul ettiğinde ise siyah ya da koyu lacivert elbise ve palto giymiş, aynı renkte de boyunbağı tercih etmiştir. Kullandığı aksesuarlar ise nadir olarak ya inci veya platin bir iğne ya da altın çifte kol düğmelerinden ibarettir. Marangozhanesinde ya da hobileriyle uğraştı̆̆ zamanlar ise kadife bir pantolon ve kolları sıvalı bir gömlekle çalışmıştır. Düz sarı renk bir ağaçtan yapılmış olan bastonunu ise sadece sarayın bahçesine çıtığında eline almış, bunun dışında kullanmamıştır. Ayakkabı tercihleri ise çizme gibi ve biraz da topukludur (Osmanoğlu, 2008, s.12).

II. Abdülhamid'in dizideki temsiline bakıldığında, fiziksel özellikleri açısından tarihsel gerçekliğiyle çeşitli farklılıklar gösterdiği gözlemlenmektedir. Bülent İnal, orta boylu olarak tasvir edilen II. Abdülhamid'in temsili için uzun boylu bir aktör olarak görünmektedir. Göz rengi ise ela değil, kahverengidir. II. Abdülhamid'in Osmanlı hanedanlığına ait fiziksel özellikleri ise Bülent İnal'ın temsilinde görülmemektedir (Osmanoğlu, 2008, s.11). Giyimi konusunda ise yalnızca kıyafetiyle aynı 
renk boyunbağı yerine zaman zaman farklı renklerde boyunbağları kostüm içerisinde kullanılmakta, bunun dişında tarihsel kayıtlara ters düşecek bir durum gözlemlenmemektedir.

Kahve içmeyi çok sevdiği bilinen Sultan II. Abdülhamid'in bu alışkanlığı hakkında Tahsin Paşa, anılarında bilgi vermektedir. Paşa, Sultan'ın, tek seferde iki fincan kahve içtiğini iletip, sonrasında ise bu kahvelerin sunumu hakkında bilgi vermektedir. Buna göre, kahvecibaşının hazırladığı kahveler, bir tepsi içerisinde iki beyaz fincan ve bir cezveyle servis yapılırmış. Birinci fincandaki kahveyi bitiren Sultan, ikincisi kahvesini başka bir fincanda içermiş (Tahsin Paşa, 1996, s. 14). Diziye bakıldığında da Sultan II. Abdülhamid'in temsilinde söz konusu olan kahve alışkanlığına sık sık yer verildiği görülmektedir. Hatta Sultan ile birlikte saraya gelen misafirlere ve huzura kabul edilen kişilere de kahve ikram edilmektedir. Aradaki fark ise dizide bu kahveler Yıldız mamulâtı olan desenli fincanlarda sunulması ve genellikle tek bir fincan bulunmasidir.

Sultan II. Abdülhamid'in kişisel özellikleri ve alışkanlıklarının yanı sıra yatak odası hakkında da bilgiler mevcuttur. Bu konuya da değinen Tahsin Paşa, bu odanın Sultan'ın kendisine ait olan dairenin birinci katında yer aldığını, odaya girildiğinde sol tarafta bir paravan ve bunun arkasında da Sultan'ın karyolası olduğunu aktarmaktadır (Tahsin Paşa, 1996, s. 15). Şehsuvaroğlu da Sultan'ın geceleri dizlerine kadar inen uzun bir gömlek giydiğini, sabah kalktığında ise üzerine bir ihram alarak banyo dairesine geçtiğini söylemektedir. Şehsuvaroğlu, Sultan II. Abdülhamid'in Şale Kasrı tarafında bulunan ve Avrupai şekilde dizayn edilmiş olan bu banyoda yıkandıktan sonra hemen banyonun karşısında bulunan bir kanepe üzerinde güneş doğuncaya kadar ibadet ettiğini aktarmaktadır (Şehsuvaroğlu, 1951, s. 1008).

Dizide padişahın bu tarz alışkanlıklarına da yer verilmektedir. Dizinin 6. bölümünde II. Abdülhamid'in uyandığı bir sahneye yer verilmekte ve Sultan uyandıktan hemen sonra ayağa kalkmadan yanında bulunan bir taş vasıtasıyla teyemmüm abdesti almaktadır. Bu sahnenin hemen arkasından Tahsin Paşa ile bir saray görevlisi arasında geçen diyalogda Sultan'ın abdestsiz yere basmaktan imtina ettiği vurgulanmaktadır. Bu diyaloğun ardından odasından çıkan Sultan, saray görevlisinin tuttuğu su ile abdestini almakta ve bir musluk başına ya da banyoya gitmemektedir. Sahnede padişah için seçilen kostüm ise elde edilen bilgilerdeki gibi uzun bir gömlektir. Ancak üzerinde bir ihram değil uzun bir hırka bulunmaktadır. Odasında bakıldığında ise elde edilen bilgilerdeki gibi herhangi bir paravan görülmemektedir. Ancak bu paravandan II. Abdülhamid hakkındaki birçok kaynakta bahsedilmektedir (Tahsin Paşa, 1996, s. 15).

Sultan II. Abdülhamid'in alışkanlıkları konusunda ulaşılabilen bir diğer bilgi ise kitaplara olan ilgisidir. Sultan'ın özellikle, polisiye ve seyahatname türünde kitaplardan hoşlandığını aktaran Tahsin Paşa, II. Abdülhamid'in bu kitapları okumak yerine çeşitli görevlilere okutarak dinlediğini söylemektedir (Tahsin Paşa, 1996, s. 15). Ayşe Osmanoğlu da geceleri kitapları sırasıyla, Esvapçıbaşı İsmet Bey, Hacı Mahmud Efendi ve Asım Bey'in okuduğu bilgisini vermektedir (Osmanoğlu, 2008, s. 33). Oysa diziye dönüldüğünde Sultan'ın bu alışkanlığına da değinildiği; ancak kitapların marangozhanede Tahsin Paşa tarafından okunduğu görülmektedir. Öte yandan okunan kitaplar polisiye türünden romanlardır.

Sultan II. Abdülhamid'in aynı zamanda bir marangoz olduğu da bilinen bir özelliğidir. Dizide bununla ilgili bilgilere ve sahnelere sıklıkla yer verilmektedir. Padişah'ın yer aldığı sahnelerin hatırı sayılır bir kısmı marangozhane olarak dekore edilmiş bir odada çekilmektedir. Bu sahnelerde ilk bölümlerde koyu renk bir önlük ve kolları sıvalı bir gömlek kostümüyle bazen de açık kahve bir yelekle temsil edilen Sultan, bazı misafirlerini burada kabul etmektedir. Söz konusu kabullerde hem devlet işleri hem de hareme dair çeşitli konular görüşülmektedir. Tahsin Paşa ise hatıratında Sultan II. Abdülhamid'in boş zamanlarında marangozhanesine giderek marangozluk işleri ile uğraştığını aktarmaktadır (Tahsin Paşa, 1996, s. 20). Söz konusu sahneler için yapılmış olan kostüm seçimi ise elde edilen bilgilerle uyum göstermektedir.

Dizide dikkat çeken bir diğer konu ise Sultan II. Abdülhamid'in aile hayatıdır. Birden fazla eşi olan ve bu kadınlardan da çocukları olan II. Abdülhamid'in harem hayatı dizinin başında modern aile yapısı 
içerisinde gösterilmektedir. Dizinin ilk birkaç bölümünde padişahın hareminde bulunan tek zevcesi Bidar Sultan, haremde görülen çocukları ise Bidar Sultan'dan olma şehzade Abdülkadir Efendi ile kız kardeşi Naime Sultan'dır. Bu bölümlerde II. Abdülhamid, sabah kahvaltılarını ailesiyle yapmaktadır. Bu sofralarda yalnızca yukarıda ismi geçen aile üyeleri yer almaktadır. Anne, baba ve çocuklardan oluşan bir sofrada Şehzade Abdülkadir Efendi ile Naime Sultan, II. Abdülhamid'e "Baba" diye hitap etmektedirler. $\mathrm{Bu}$ şekilde II. Abdülhamid, padişahlık vasfından uzaklaştırılarak sıradan bir baba olarak gösterilmektedir. Bu sahnelerde yalnızca Bidar Kadın'ın II. Abdülhamid'e "Hünkârım" şeklinde hitap etmesi, sofrada bir babanın değil, padişahın oturduğunu hissettirmektedir. Ancak ilerleyen bölümlerde II. Abdülhamid'in bir diğer zevcesi olan Fatma Pesend Hanım, diziye dâhil olmaktadır. Fatma Pesend Hanım'ın Paris'ten geldiği bilgisi verilmektedir ve geldiğinde hamiledir. II. Abdülhamid'in hayatı hakkında elde edilen bilgilere bakıldığında ise dizide yer alanların yanı sıra altı zevcesinin daha olduğu bilinmektedir. Kadınefendilerin yanı sıra ikbal sıfatıyla padişahın hareminde yer alan zevceleri de vardır (Yılmaz, 2013, s. 116).

II. Abdülhamid'in aile hayatıyla ilgili bilgilere bakıldığında dizide bu yönde çok fazla eksiklik olduğu gözlemlenmektedir. Kendisinden başka kadınefendiler olmasına rağmen dizinin başında haremde sadece Bidar Kadınefendi yer almakta ve haremi tek başına idare etmektedir. Yalnızca Seniha Sultan ile arasında geçen bir diyalogda II. Abdülhamid ile boşanmış olan Nurefsun Kadınefendi'den bahsedilmektedir. Nurefsun Sultan haremde bulunan kadınlarla anlaşamamasını gerekçe göstererek Padişah'tan kendisini boşamasını istemiş bir sultandır (Yılmaz, 2013, s. 111). Ancak dizide bu bilginin aksine uygunsuz davranışları sebebiyle padişahın isteği üzerine boşandığı bilgisi verilmektedir. Diğer zevcelerin bahsi dahi geçmezken sonradan diziye dâhil olan Fatma Pesend Hanım'ın ise Paris'e gittiği ve bir müddet orada yaşadığına dair elde edilmiş herhangi bir bilgi yoktur.

Bu dönemde genellikle Yıldız Sarayı içerisindeki dairelerinde ikamet eden şehzadelerin kendilerine ayrı daireleri, maiyetleri ve teşkilatları bulunmaktaydı (Paşa, 1996, s. 29). Ancak dizinin başlangıcında annesi Bidar Kadınefendi gibi sarayda yaşayan tek şehzade Abdülkadir Efendi'dir. Dizinin ilerleyen bölümlerinde Şehzade Burhaneddin Efendi de diziye dâhil olmakta; ancak saray dışında bilgisi verilmeyen bir yerden padişah tarafından davet edilmektedir. Bu durum ise şehzadelerin saray içerisinde yaşadıkları bilgisiyle örtüşmemektedir (Tahsin Paşa, 1996, s. 29).

Dizide harem hayatı temsil edilen II. Abdülhamid'in, ilk bölümlerde modern bir çekirdek aile içerisinde gösterilirken, sonraki bölümlerde dâhil olan Fatma Pesend Hanım, Şehzade Burhaneddin Efendi'yle başka zevce ve çocuklara sahip olduğu izlenimi verilmekte; ama bu kadarla sınırlı tutulmaktadır. Bu duruma bakıldığında Sultan Abdülhamid'in aile hayatının ve dönemin harem yaşantısının temsilinde eksik bilgiler olduğu gözlemlenmektedir ve inşacı bir temsil yaklaşımı ortaya çıkmaktadır.

\section{Sonuç}

Medya, birçok farklı alan ve konu ile ilgilenmektedir. Bu bağlamda tarihe de ilgi duymuş; tarihi olay ve karakterleri günümüze taşıyarak popüler bir ürün haline getirmiştir. Zaman içerisinde çeşitli televizyon dizilerinin konusunu oluşturan tarih, bu mecralarda yoğun bir ilgi görmüş ve her dönem buradaki yerini almıştır. Ancak, tarihin medyada bu kadar yer edinmesi ve seyirciler tarafından talep görmesi belirli sorunları da beraberinde getirmiştir. Her şeyden önce bilgiye ulaşmak açısından ciddi kolaylık sunan ve temsilden ziyade gerçeklik iddiasıyla ekranları dolduran televizyonda doğru ile yanlış birbirine karışmıştır. Bu bağlamda gerçeklik açısından ortaya çıkan bu sorun, tarih dizileri konusunda da ciddi soruların akıllara gelmesine sebep olmuştur. Bu sorulardan bir tanesi de tarihsel olaylar ve kişiler aktarılırken oluşturulan temsillerin gerçeklikle ne ölçüde uyumlu olduğudur.

Bu çalışmada, Payitaht “Abdülhamid” adlı dizi, mekân, kostüm, makyaj ve dekor gibi açılardan ele alınıp incelenmiştir. Seta Film Platosu'nda hazırlanan dizi için Yıldız Sarayı ve döneme ait diğer mekânların temsilleri oluşturulmuştur. Gerçeği ile birebir benzer olma iddiası taşıyan bu mekânlar, görsel olarak bu 
benzerliği taşısa da izleyiciye verilen bilgiler açısından eksiklikler taşımaktadır. Kostüm açısından yapılan incelemelere bakıldığı zaman ise elde edilen verilerden dizide sıklıkla yönetmenin ve sanat yönetmeninin hayal gücünü kullanarak belli noktalarda televizyonun görsel çekiciliğine hizmet edecek seçimlerde bulunduğu sonucu ortaya çıkmıștır. Kullanılan dekorlara bakıldığında ise dönemin şartlarına uygunluk gösterdikleri gözlemlenmektedir; ancak tıpkı kostümler gibi elde edilen veriler dizi içerisinde kullanılan tüm mekânları besleyecek yeterlilikte değildir. Bu noktada yönetmenin kendi inisiyatifinde olan ve var olan boşlukları doldurduğu temsil yaklaşımı olan inşacı temsil yaklaşımının sıklıkla kullanıldığ1 gözlemlenmiştir.

Sultan II. Abdülhamid'in iktidarının belli bir dönemini konu edinen dizide Hükümdar'ın görsel temsili de önem taşıyan bir diğer başlıktır. II. Abdülhamid hakkında elde edilen yazılı kaynaklara ve fotoğraflara bakıldığında II. Abdülhamid'in, kendisini canlandıran Bülent İnal'ın fiziksel özellikleriyle uyuşmadığı görülmektedir. Bülent İnal orta boylu olarak bilinen II. Abdülhamid temsili için uzun görünmektedir. Yine kaynaklarda, II. Abdülhamid, omuzları kambur, burnu ise kemerli ve büyük olarak aktarılmaktadır. Ancak onu canlandıran Bülent İnal, bir aktör olarak daha düzgün hatlara sahiptir. II. Abdülhamid ile yakın bağları olan kişilerin yazdı̆̆ı hatıratlardan elde edilen verilere bakıldığında Sultan'ın belirgin olan alışkanlıkları izleyiciye sunulmaya çalışılmıştır. Ancak bunlar da yine televizyonun izin verdiği ölçüde ve izleyicide belli bir ilginin uyanmasını sağlayacak şekillerde kullanılmış, belli durumlar için gerçek olanın yerine farklı mekânlar kullanılarak dizi için oluşturulan hikâyenin içerisine yerleştirilmiştir. Burada göze çarpan unsurlardan bir tanesi de II. Abdülhamid'in aile hayatıdır. Osmanlı hükümdarlarının klasik harem hayatı gibi II. Abdülhamid'in de birden fazla eşi ve cariyesi olmasına rağmen dizinin başlangıcında modern aile yaşantısına sahip bir padişah olarak temsil edilmiş, ilerleyen bölümlerde ise eşleri ve çocuklarının hepsi değil, yalnızca bir kısmı diziye dâhil edilmiştir. Dizide ayrıca sıklıkla dini göstergelere yer verilerek II. Abdülhamid'in dindar bir hükümdar olduğunun altı çizilmiştir. Başta çeşitli mekanlarda oluşturulan dekorlar için kullanılan dini içerikli tablolar olmak üzere, camii sahneleri II. Abdülhamid'in söylemleri bu bilgiyi pekiştirmek adına kullanılmıştır.

Elde edilen veriler toparlandığında tarih dizilerinde gerek bütçe gerek ideolojik sebepler gerekse de aktarmak istenilen mesajın etkisini artırmak adına olgusal gerçeklik üzerinde çeşitli değişikler yapılabildiği gözlemlenmiştir. İzleyicinin talebi doğrultusunda, reyting kaygısı ile üretilen içeriklerde gerçeklik göz ardı edilmekte; bunun yerine gerçekliğin bir temsili ile yeni bir dünya inşa edilmektedir. Bu sayede televizyon belli bir ideolojiyi topluma yansıtma amacına hizmet eden bir araç olmaktadır. Dolayısıyla toplumsal bellekte dizide sunulan bir padişah imajı oluşturulmaktadır. Böyle bir ortam içerisinde de gerçeklik ile kurmaca arasındaki fark bulanıklaşmaktadır. Televizyon, gerçekliğin bir temsilini oluştururken ona tamamen bağlı kalmak yerine belirli oranlarda onları yenden üretmektedir İçerikler için oluşturulan mekân, kostüm ve dekor gibi unsurlar seçilirken gerçeği ile birebir aynı olmasından ziyade bütçe başta olmak üzere izleyici üzerinde etki edebilecek ve içerikte sunulan bilgileri pekiştirecek öğeler dikkate alınmaktadır. Öte yandan tarih konusunda her türlü detaya erişilememesi ve belirli alanlarda boşlukların kalması gibi durumlarda yönetmenin ve teknik ekibin hayal gücü doğrultusunda söz konusu eksiklikler tamamlanmaya çalışılmaktadır.

Gündelik hayatın bir parçası olan ve gerçek hayatta olup bittiğini bildiğimiz olayları içerik olarak sunan televizyonun yansıttığı görüntüler izleyiciler tarafından gerçek olarak kabul edilmektedir. Ancak ekranlardan deneyimlenen bu gerçeklik yine ekran aracılığıyla dolaylı olarak aktarılan bir gerçekliktir. Televizyon için öncelikle ekrana hangi olayın ve bunun ne kadarının yansıtılacağına karar verilmekte sonrasında ise belirlenen bu olay sübjektif olarak seçilen kamera açılarıyla ekrana aktarılmaktadır.

Yapılan analizler sonucunda başlangıçta ortaya atılan hipotezin doğrulandığını söylemek mümkündür. Bu bağlamda, tarihsel gerçekliklerin televizyona aktarılırken temsil yaklaşımlarından en az bir tanesi kullanılmaktadır. Örneklem olarak ele alınan Payitaht "Abdülhamid" dizisinde yansıtıcı yaklaşım sıklıkla kullanılırken, yer yer inşacı yaklaşım ile tasarlanmış sahnelere rastlamak da mümkündür. Dizide yansıtıcı 
temsil yaklaşımı ile olgusal gerçekliğe yaklaşma konusunda başarı gösterilmiştir. Ancak, inşacı temsil yaklaşımının kullanılması, birçok yerde doğru bilgilerin önüne geçmektedir. Buradan yola çıkılarak da denilebilir ki tarih dizileri, oluşturulan temsillerle çeşitli etkenlere bağlı olarak kısıtlı dahi olsa kısmen olgusal gerçeklikten uzaklaşabilmektedirler.

\section{Kaynakça}

\section{Kitaplar}

Adanır, O. (2003). Sinemada Anlam ve Anlatım. İstanbul: Alfa Basım Yayım ve Dağıtım Ltd. Şti.

Apak, D. D., Melek Sevüktekin (1997). Osmanlı Dönemi Kadın Giyimleri. Ankara: Türkiye İş Bankası Barthes, R. (1979). Göstergebilim İlkeleri. (B. V.-M. Rifat, Çev.) Kültür Bakanlığı Yayınları.

Baudrillard, J. (2002). Tam Ekran. (B. Gülmez, Çev.) İstanbul: Yapı Kredi Yayınları.

Berger, A. A. (2018). Medya Çözümleme Teknikleri, (Nilüfer Pembecioğlu Çev.) Ankara: Nobel Akademik Yayıncılık.

Dağgülü, M. (1993). Yıldız Sarayı-Selamlık Bahçesi (Tespit ve Envanter Çalışması). İstanbul: Yıldız Teknik Üniversitesi Mimarlık Fakültesi Baskı İşliği

Engin, V. (2018). Bir Devrin Son Sultanı II. Abdülhamid. İstanbul: Yeditepe Yayınları

Görünür, L. (2010). Osmanlı İmparatorluğu'nun Son Döneminden Kadın Giysileri- Sadberk Hanım Müzesi Koleksiyonu. İstanbul: Vehbi Koç Vakfı

Hall, S. (2017). Temsil İşi. S. Hall içinde, Temsil: Kültürel Temsilller ve Anlamlandırma Uygulamaları (İ. Dündar, Çev., s. 21-84). İstanbul: Pinhan Yayıncıllı.

İrez, F. (1988). XIX. Yüzyıl Osmanlı Saray Mobilyası. Ankara: Ankara Kültür Merkezi Yayını.

Koçu, R. E. (1969). Türk Giyim Kuşam ve Süslenme Sözlüğü. Sümerbank Kültür Yayınları.

Karahüseyin, G. (2009). Bir Döneme Işık Tutanlar "19. YY. Osmanlı Saraylarında Aydınlatma Araçları Koleksiyonu". İstanbul: TBBM Milli Saraylar .

Kolker, R. (2009). Film, Biçim ve Kültür. Ankara: De Ki Basım Yayım LTD

Mutlu, E. (2008). Televizyonu Anlamak. Ankara : Ayraç Kitabevi.

Osmanoğlu, Ş. (2012). Babam Abdülhamid - Saray ve Sürgün Yılları. İstanbul: Timaş Yayınları.

Osmanoğlu, A. (2008). Babam Sultan Abdülhamid-Hatıralarım. İstanbul: Selis Kitaplar.

Özer, İ. (2014). Osmanlı'dan Cumhuriyet'e Yaşam ve Moda. İstanbul: Truva Yayınları

Özön, N. (1985). Sinema Uygulayımı, Sanatı, Tarihi. Hil Yayınları

Rifat, M. (2009). Göstergebilimin ABC'si. İstanbul: Say Yayınları.

Sarıgül A. F. (2019). Popüler Kültür Nedir? Ne Değildir?. İstanbul: Altınbaş Üniversitesi Yayınları.

Şehsuvaroğlu, H. Y. (2011). Tarihi Odalar. İstanbul: TBMM Milli Saraylar.

Tahsin Paşa (1996). Sultan Abdülhamid "Tahsin Paşa'nın Yıldız Hatıraları. İstanbul: Boğaziçi Yayınları. 
Yaylagül, L. (2016). Kitle İletişim Kuramları Egemen ve Eleştirel Yaklaşımlar. Ankara: Dipnot Yayınları.

Yaylagül, Ö. (2015). Göstergebilim ve Dilbilim. Ankara: Hece Yayınları.

Y1lmaz, H. (Dü.). (2009). Sultan II. Abdülhamid'in Aile Albümü. İstanbul: İBB Kültür A.Ş.

Yılmaz, Ö. F. (2013). Sultan II. Abdülhamid Han'ın Aile Hayatı. İstanbul: Çamlıca.

\section{Makaleler}

Lüleci, Y. (2019). Bir II. Dünya Savaşı Türkiyesi Temsili Olarak Kelebeğin Rüyası Filmi, Egemia (5), 187-211.

Parsa, P. D. (1999). Televizyon Göstergebilimi. Kurgu Dergisi (16), 15-28.

Sevgin, E. (1966). İstanbul Saraylarında Adım Adım "Yıldız Sarayı". Hayat Tarih Mecmuası, 1 (5), 38-47

Şehsuvaroğlu, H. Y. (1951). Abdülhamid'in Yıldız'daki Hususi Dairesi ve Oradaki Yaşayış Tarzı. Resimli Tarih Mecmuas1, 2 (22), 1005-1009.

\section{Tezler}

Arıburun, L. N. (2012, Mart). 19. Yüzyıl Osmanlı Saray Mobilyaları: Batılılaşma Etkisi ve Biçimsel Açıdan Yemek Kültüründeki Değiş̧im Süreci. İstanbul Teknik Üniversitesi, Fen Bilimleri Enstitüsü, Endüstri Ürünleri Tasarımı Bölümü Doktora Tezi . İstanbul.

\section{İnternet Kaynakları}

Görsel Sanatlar Platformu. (2008). Temmuz 08, 2019 tarihinde gorselsanatlar.org: http://www.gorselsanatlar.org/guzel-sanatlar-fakulteleri/sanat-yonetimi-bolumu/ adresinden alınd. 